\title{
Information System? Which One Do You Mean?
}

\author{
João Alvaro Carvalho \\ Information Systems Department, University of Minho, 4800 Guimarães, Portugal \\ Email:jac@dsi.uminho.pt
}

Key words: Information, System, Information system

\begin{abstract}
Information systems and technology is an emerging area of human knowledge that experiences some difficulties related to a lack of consensus about its more basic concepts and terminology. Instances of problematic terms are information and information system. Any person attending conferences or reading books and papers related to information systems will soon discover that there is more than one possible meaning for the term information system. In other words, people that talk or write about information systems aren't always referring to the same object. The distinctions among the different objects that can be viewed as information systems are not always clear because they have many aspects in common: they all deal with information; they all are somewhat related to organisations or to the work carried out in organisations; and they all are related to information technology, either because they can benefit from its use or because they are made with computers or computerbased devices.

In this paper it is claimed that a more elaborated view of the system concept might bring some light to this problem. Using a specific definition of system, it will be argued that: there are four different objects that, legitimately, can be considered information systems; all of these objects are interesting objects in the area of IST; each of them is useful for different professional activities. The four objects will also be associated with several definitions of information systems proposed in different works, including the definition proposed in the FRISCO Report.
\end{abstract}

The original version of this chapter was revised: The copyright line was incorrect. This has been corrected. The Erratum to this chapter is available at DOI: 10.1007/978-0-387-35500-9_30 


\section{INTRODUCTION}

Browsing the literature in the area of information systems and technology ${ }^{1}$ (IST) anyone quickly comes to the conclusion that there is no agreement on what an information system is! However, the problem is not related with a lack of consensus on an adequate wording for a definition. The problem is that the same term - information system - is being used to designate different things. And the distinction among the different information systems is not always clear because they have several aspects in common: they all deal with information, they all are somewhat related to organisations or to the work carried out in organisations, and they all are related to information technology, either because they can benefit from its use or because they are made with computers or computer-based devices.

Although some effort has been made to clarify the nature of information systems (e.g., [Falkenberg and Lindgreen 1989], [Falkenberg, et al. 1992], [Falkenberg, et al. 1996], [Weber 1997], [Checkland and Holwell 1998]) certain aspects aren't clear yet. A more elaborated view of the system concept might bring some light to this problem. Using a definition of system based on the work of Le Moigne [Le Moigne 1977], I will argue that: there are four different objects that, legitimately, can be considered information systems; all of these objects are interesting objects in the area of IST; each of them is useful for different professional activities.

The four objects will also be associated with several definitions of information systems proposed in different works, including the definition proposed in the FRISCO Report [Falkenberg, et al. 1996].

The objective is not to provide yet another definition for information system or to develop a taxonomy of information systems but to review and compare possible meanings for the term, and distinguish among several concepts hidden in the same designation.

${ }^{1}$ Often, the area is designated simply by information systems (e.g., [Buckingham, et al. 1987], [Mingers and Stowell 1997], [Checkland and Holwell 1998]). However, in order to avoid the use of the same term - information system - to designate both an object of scientific interest and the area of human knowledge about that object, we decided to use the term "information systems and technology" to designate the latter. Attending to the importance of information technology in the area, it can be argued that this designation is more adequate. Bacon and Fitzgerald [Bacon and Fitzgerald 1996] present an interesting argument to justify its adoption. 


\section{INFORMATION, SYSTEMS, AND INFORMATION SYSTEMS}

It is important to start by defining the two basic concepts of information and system. The risk undertaken is that there isn't agreement either on the meaning of these two important terms. So, the definitions proposed herein might be rejected by some of the readers. However, the necessity of presenting these two definitions is undeniable.

System is a concept that is useful to study active objects, especially when they are complex. A system is the result of viewing the active world from a certain point of view. Any thing (and specially an active thing) can be viewed as being a system. A system (in general or in abstract) can be defined as an active (does something), stable (has a structure ...) and evolutionary (... that changes over time) thing or object that operates in an environment (it interacts with other things) with some purpose (from the point of the view of the modeller, there is a reason for the system to do what it does) [Le Moigne 1977]. It should be noted that the adoption of a less strict definition of system is frequent. To some authors (e.g., [Ackoff 1971], [Laszlo 1983], [Boulding 1985], [van Gigch 1991], [Bunge 1979], [von Bertalanffy 1975], [Jordan 1968]), a system is just something whose components are inter-related. The adoption of Le Moignes's definition in this work is justified by the richness it brings to the systemic study of an object.

Simple systems are mere active objects without self-control and with no cognitive capacities. More complex systems have some kind of control upon what they do. They are also able of learning and making decisions and they can reach a high level of autonomy, i.e., they might have independent existence, they are capable of governing them selves and surviving in a changing (and sometimes hostile) environment. In this case, systems need knowledge and perform several operations upon that knowledge ${ }^{2}$. In between it is possible to identify different levels of self-control.

It will be considered that an autonomous system (e.g., an organisation) can be sub-divided in three sub-systems: operational, managerial, and informational. The operational sub-system includes those activities that perform actions directly related to the system's purpose or mission (and perhaps some supporting actions). The managerial sub-system includes the

2 Several authors recognise that systems can be more or less elaborate and propose classifications of systems according to the level of complexity and characteristics they possess (e.g., [Boulding 1956], [Boulding 1985], [Ackoff 1971], [von Bertalanffy 1975], [Jordan 1968], [Checkland 1981], [Bunge 1979], [Le Moigne 1978a], [van Gigch 1974], [Laszlo 1983]; a summary view of systems definitions and classifications can be obtained in [Skyttner 1996]). 
activities that manage (organise, plan, control, coordinate, etc.) the operational activities. The informational sub-system establishes communication among the other two sub-systems. The necessity of the informational system is particularly clear when that communication is asynchronous and the existence of mechanisms that support the memorisation and retrieval of information is evident.

Figure 1 illustrates this view of autonomous systems. Although it can be considered as a simplistic view, it is considered to be useful to the purposes of this paper.

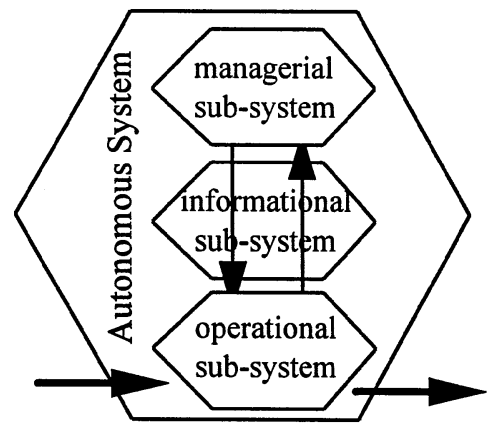

Figure 1. - Sub-systems of an autonomous system. The thicker arrows illustrate the modification produced by the system; the other arrows illustrate the communication between the operational and managerial sub-system; this communication is performed through the informational sub-system

The action of a system alters some other object(s). The altered object can be either passive (matter, energy or information) or active (in such case it can also be viewed as a system). In the first case, the alteration can change the object in its form, in space or in time. In the second case, the alteration modifies the structure of the object. Table 1 summarises the types of alterations that a system can produce and the types of objects that can be altered.

Table 1. Types of alterations that a system can produce and the types of objects that can be altered; the table shows some words normally used to refer to some of the alterations

\begin{tabular}{|c|c|c|c|c|}
\hline \multicolumn{2}{|c|}{ changed objects } & form & space & time \\
\hline \multirow{2}{*}{$\begin{array}{c}\text { passive } \\
\text { objects }\end{array}$} & matter & transformation & transportation & storage, stocks \\
\cline { 2 - 5 } & energy & conversion & transportation & accumulation \\
\cline { 2 - 5 } & information & processing & transmission & storage, memory \\
\hline \multirow{2}{*}{$\begin{array}{c}\text { active } \\
\text { objects }\end{array}$} & system & \multicolumn{2}{|c|}{ the alteration of a system addresses its structure } \\
\hline
\end{tabular}


Information is herein understood as symbolic objects ${ }^{3}$ (opposed to material and energetic objects) deliberately built in order to enable communication and the formation of knowledge.

It should be noted that the criteria used to define information are related to the object's nature: matter, energy or information. This criteria is rather different from the one used in the FRISCO report, where information is defined as a form of knowledge ("the knowledge increment..."). FRISCO's definition of information is however too far from its usage in common language and this makes it very difficult to apply. This is perhaps a major inconvenient to its widespread adoption and use. FRISCO's concept of data ("... collection of representations...") is closer to the concept of information as defined in this work.

Sometimes, the term information is also used to refer to the act of informing i.e., the action of providing the means to the construction of knowledge (in this case, information is a noun that names an action). These two meanings for information are, however, inter-related: the latter refers to an action (to inform) and the former to the means used to achieve that action (symbolic objects or representations).

Based on the definitions of information and system provided in the previous paragraphs, it is legitimate to conclude that an information system is either: (i) an active object that deals with (processes) information; or (ii) an active object whose purpose is to inform.

The first interpretation focuses the nature of the processed objects. Information systems are systems that process only information, i.e., symbolic objects or representations. Material and energetic objects are not considered to be relevant. Processed objects can be affected in its form, space and time. In the case of information, the possible operations upon it might include: calculate, process, create, code, decode (form); collect, present, transmit (space); store, memorise (time). So, any active object that carries out any of these operations might be entitled to be considered an information system.

The second interpretation focuses on the purpose of the system. Information system is a system whose purpose is to inform, i.e., to contribute to someone's acquisition of knowledge. This knowledge is necessary to the execution of some action in some context.

It is also possible to consider that an information system is an active object that deals with (processes) symbolic objects AND whose purpose is to inform. This third interpretation is a combination of the other two. The existence of such a system is very plausible as a system that informs its

3 As the symbolic objects are used to represent other things they can also be called representations. 
clients/users has to deal with information. However, it should be noted that not all systems that deal with information have the purpose of informing. Insurance companies and banks are two examples of such systems.

\section{FOUR OBJECTS ENTITLED TO BE CONSIDERED INFORMATION SYSTEMS}

The criteria for identifying objects that can be considered information systems is now set. The identification of information systems within, or related to, organisations can be started at the level of the organisation itself. Organisations whose purpose is to provide information to their clients can be considered information systems:

IS1 - Organisations (autonomous systems) whose business (purpose) is to provide information to their clients. The following are some examples of objects that can be considered as IS1 information systems: libraries, information services, information brokers, newspapers, radio or TV stations.

Looking inside organisations, other information systems will emerge. In any organisation, viewed as an autonomous system (i.e., a system that is capable of governing itself) it is possible to identify a sub-system that assures the communication between the managerial and operational subsystems of an organisation (cf. section 2). Such organisational sub-system is an information system:

IS2 - A sub-system that exists in any system that is capable of governing it self (autonomous system). The information system (IS2) assures the communication between the managerial and operational sub-systems of an organisation - that's its purpose. When this communication is asynchronous, a memory to store the messages is necessary. IS2 includes such memory.

IS2 makes extensive use of computer-based artefacts to support their functionality. Such artefacts process information, acting upon its form, space, or time: calculate, process, create, code, decode (form); collect, present, transmit (space); store, memorise (time). The purpose of these artefacts (systems) may vary according to the operations they actually perform and the intentions of their creators and users. However, the use of these artefacts in organisations is not restricted to the boundaries of IS2. They can be used to support or automate any organisational activities that deal with information irrespective of their "affiliation" to any of the three 
organisational sub-systems identified above: operational, managerial or informational. So, the third information system is the following:

IS3 - Any combination of active objects (processors) that deal only with symbolic objects (information) and whose agents are computers or computer-based devices - a computer-based system. IS3 can be used in organisations to support or automate any activities (organisational work) that deal with information, irrespective of their "affiliation" to the operational, managerial or informational sub-systems of an organisation). The purpose of these systems may vary according to the operations they actually perform [Carvalho 1998] and the intentions of their creators and users. Examples of IS3s include artefacts such as: transaction processing systems, data processing systems, management information systems, decision support systems, workflow management systems, data mining systems, environmental scanning systems, executive information systems.

The apperception that activities that deal with information exist all over an organisation (and are not restricted to its informational sub-system) leads to the identification of another information system:

IS4 - Any combination of active objects (processors) that deal only with symbolic objects (information). When applied to an organisation, this view corresponds to all organisational activities excepting those that deal with materials or energy.

In certain cases, an IS4 may coincide with the whole organisation, or at least be very close to it. One such case is when the organisation is an IS1. Another case is when the organisation, despite not having the purpose of informing its clients, deals solely with symbolic objects. Examples of such orgánisations are banks, insurance companies, software houses, architecture offices, etc.

IS4 poses a problem from the point of view of a systemic analysis: purpose. IS4s have no purpose in themselves! An IS4 is perhaps more adequately described as a sub-set ${ }^{4}$ of an organisation that includes any information handling activities, irrespective of being carried out within the operational, the managerial, or the informational sub-system. Another way of describing IS4 would be as abstractions of organisations that include the activities that deal with information. This view leads to the conclusion that most of an organisation is an information system.

${ }^{4}$ Sub-set is used to call the attention to the fact that IS4 is not identified as a sub-system whose purpose is necessary to achieve the purpose of its supra-system (the organisational system). IS4 is identified as anything, within the organisational system, that deals with information. 
Using Le Moigne's definition of system, introduced in section 2, it is difficult to consider IS4 as a system because it is not possible to ascribe it a purpose. However, it should be recognised that Le Moigne's definition of system is more restrictive than other common definitions of system. So IS4 might only be considered a system, if a definition of system less restrictive that Le Moigne's is adopted. In spite of that, in the remainder of this paper, this fourth object will be called an information system.

The four information systems are schematically depicted in figure 2 .

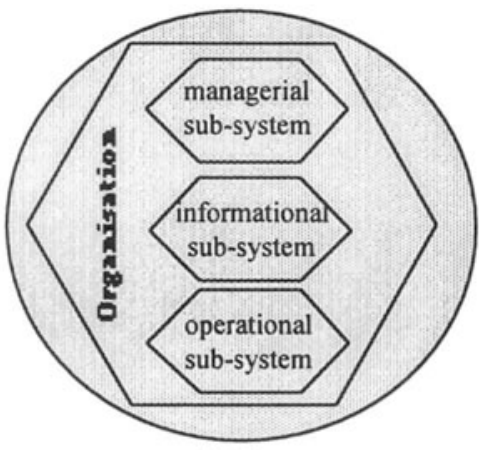

IS1

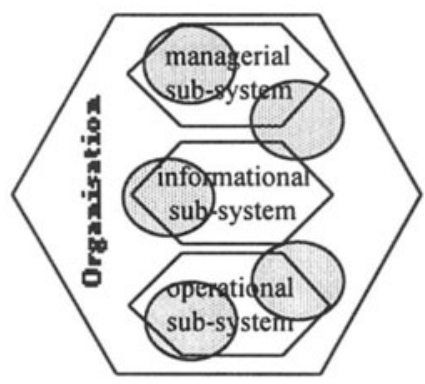

IS3

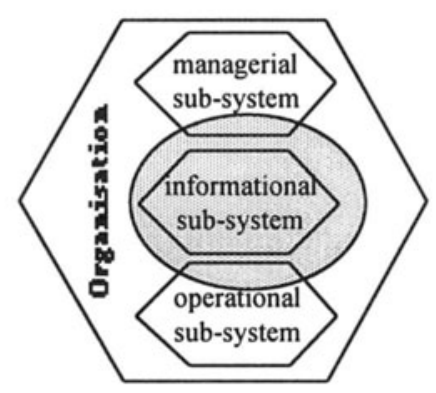

IS2

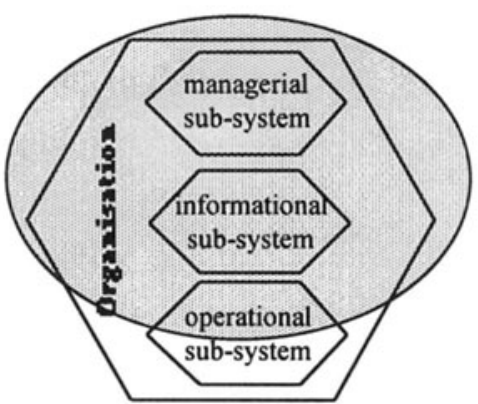

IS4

Figure 2. Schematic representation of four different objects that can be considered information systems: IS1 is an organisation whose purpose is to inform its clients; IS2 is an organisational sub-system that supports communication between the operational and the managerial sub-systems. Such sub-system exists in any autonomous system (i.e., a system capable of self-govern); IS3 is any artefact that uses computers and computer-based devices to perform information manipulation activities; IS4 is a sub-set of an organisation that encompasses all information manipulation activities; if the organisation deals only with information, IS4 includes all the organisational activities; however, it is distinct from an IS1 information system as, in a IS4 there is no reference to purpose (each IS is delimited by a circle). 
Table 2 summarises the characteristics of the four objects that can be considered information systems according to some features derived from the system view presented in section 2 .

Table 2. Summary of the characteristics of IS1, IS2, IS3 and IS4 information systems

\begin{tabular}{|c|c|c|c|c|}
\hline & IS1 & IS2 & IS3 & IS4 \\
\hline $\begin{array}{l}\text { i) Processed } \\
\text { objects }\end{array}$ & Information & Information & Information & Information \\
\hline $\begin{array}{l}\text { ii) Operations } \\
\text { upon the } \\
\text { processed objects }\end{array}$ & $\begin{array}{l}\text { Some or all the } \\
\text { possible } \\
\text { operations }\end{array}$ & $\begin{array}{l}\text { Some or all the } \\
\text { possible } \\
\text { operations }\end{array}$ & $\begin{array}{l}\text { Some or all the } \\
\text { possible } \\
\text { operations }\end{array}$ & $\begin{array}{l}\text { Some or all } \\
\text { the possible } \\
\text { operations }\end{array}$ \\
\hline $\begin{array}{l}\text { iii) Purpose of the } \\
\text { system }\end{array}$ & To inform & $\begin{array}{l}\text { To inform } \\
\text { (assure } \\
\text { communication } \\
\text { between the } \\
\text { operational and } \\
\text { managerial } \\
\text { sub-systems }\end{array}$ & $\begin{array}{l}\text { Is normally } \\
\text { related to some } \\
\text { support to } \\
\text { information } \\
\text { manipulation } \\
\text { activities }\end{array}$ & $\begin{array}{l}\text { No purpose } \\
\text { can be } \\
\text { ascribed }\end{array}$ \\
\hline \multicolumn{5}{|c|}{ iv) Nature of the agents that perform the operations: } \\
\hline - Humans & yes & yes & no & yes \\
\hline $\begin{array}{l}\text { - Non-computer- } \\
\text { based information } \\
\text { technology }\end{array}$ & yes & yes & no & yes \\
\hline $\begin{array}{l}\text { - Computers and } \\
\text { computer-based } \\
\text { devices }\end{array}$ & yes & yes & yes & yes \\
\hline \multicolumn{5}{|c|}{ v) Environment of the system: } \\
\hline - Context & $\begin{array}{l}\text { The } \\
\text { organisational } \\
\text { environment }\end{array}$ & $\begin{array}{l}\text { The other } \\
\text { organisational } \\
\text { sub-systems: } \\
\text { operational and } \\
\text { managerial; } \\
\text { the } \\
\text { organisational } \\
\text { environment }\end{array}$ & $\begin{array}{l}\text { People that use } \\
\text { the system (or } \\
\text { benefit form its } \\
\text { existence) and } \\
\text { their work } \\
\text { context; }\end{array}$ & $\begin{array}{l}\text { The } \\
\text { organisation } \\
\text { and its } \\
\text { environment }\end{array}$ \\
\hline - Clients/users & $\begin{array}{l}\text { The } \\
\text { organisation's } \\
\text { clients }\end{array}$ & $\begin{array}{l}\text { Organisational } \\
\text { agents } \\
\text { belonging to } \\
\text { the managerial } \\
\text { and operational } \\
\text { sub-systems }\end{array}$ & $\begin{array}{l}\text { People that } \\
\text { "handle" the } \\
\text { system } \\
\text { (normally } \\
\text { called "users") }\end{array}$ & $\begin{array}{l}\text { Organisation } \\
\text { agents and a } \\
\text { sub-set of the } \\
\text { organisation's } \\
\text { environment }\end{array}$ \\
\hline
\end{tabular}


Table 2 (cont.) Summary of the characteristics of IS1, IS2, IS3 and IS4 information systems

\begin{tabular}{|c|c|c|c|c|}
\hline & IS1 & IS2 & IS3 & IS4 \\
\hline $\begin{array}{l}\text { vi) Degree of self } \\
\text { control }\end{array}$ & $\begin{array}{l}\text { Autonomous } \\
\text { system }\end{array}$ & $\begin{array}{l}\text { Normally it } \\
\text { doesn't have } \\
\text { any kind of } \\
\text { self-control. } \\
\text { But it is a } \\
\text { necessary sub- } \\
\text { system in any } \\
\text { autonomous } \\
\text { system }\end{array}$ & $\begin{array}{l}\text { Normally, an } \\
\text { IS3 system is a } \\
\text { system without } \\
\text { any kind of } \\
\text { self-control, } \\
\text { even thought } \\
\text { that an IS3 } \\
\text { system can } \\
\text { automate the } \\
\text { control } \\
\text { function within } \\
\text { a system. }\end{array}$ & $\begin{array}{l}\text { As it is not } \\
\text { possible to } \\
\text { ascribe it a } \\
\text { purpose, it } \\
\text { doesn't make } \\
\text { sense to talk } \\
\text { about self- } \\
\text { control }^{5} \text {. }\end{array}$ \\
\hline
\end{tabular}

The features are the following ${ }^{6}$ :

i) nature of processed objects (information, material, energy);

ii) operations upon those objects; the operations processing information upon its form space and time and might include: calculate, process, create, code, decode (form); collect, present, transmit (space); store, memorise (time);

iii) purpose of the system;

iv) nature of the agents that carry out the operations; the agents might be: humans, non-computer-based information technology (e.g., paper, microfilms, photocopying machines, telephones, fax, etc.); or computers and computer-based devices;

v) the environment within the information system operates; in what concerns the environment, it might be useful to distinguish the context and the clients/users of the information system;

vi) degree of self control; whether the system is autonomous or, at least, has any kind of self control.

${ }^{5}$ As an IS4 consumes resources, it is however possible to associate it with some sort of resource management function.

${ }^{6}$ The features used to compare the different objects that might be considered information systems include most of the elements considered by Checkland [Checkland 1981] in the definition of a system: Clients, Actors, Transformation, Weltanschauung, Owner, Environment (CATWOE). Clients and Environment are grouped in item v). Actors are included in item iv) although only their nature is considered to be relevant. Transformation is somewhat considered in item ii) and iii).

${ }^{7}$ Although this will be a constant in all information systems, this aspect is central to the issue in discussion. 
Features i) and ii) are common to the four ISs. Focusing only on these two features it is possible to formulate a definition that is suitable to fit all the four ISs. However, the four ISs are very different in what relates to the remainder features, supporting the argument that they really are different systems. Table 3 provides some examples for each IS.

Table 3. Examples of IS1, IS2, IS3 and IS4

\begin{tabular}{|l|l|}
\hline IS & \multicolumn{1}{c|}{ Examples } \\
\hline IS1 & CNN; EU's Cordis; a weather service \\
\hline IS2 & $\begin{array}{l}\text { The following are part of the IS2 information system: data base; } \\
\text { procedures manual; accounting books }\end{array}$ \\
\hline IS3 & $\begin{array}{l}\text { A transaction processing system; a computer based data base; a decision } \\
\text { support system; an expert system }\end{array}$ \\
\hline IS4 & Any organisation can be viewed as an IS4 information system \\
\hline
\end{tabular}

\section{INFORMATION SYSTEM DEFINITIONS: PRESENTATION}

Considering the existence of four different things that can be considered information systems, an interesting question to raise is which IS (or ISs) might fit different definitions of information system.

The definitions considered in this section have been searched in the IST literature especially in introductory textbooks or in books and papers that address the question of what is an information system. Any intention of being exhaustive or systematic was soon abandoned when it became evident that there are too many different definitions and that many authors do not bother to define the concept. This isn't always problematic, as it's normally easy to recognise the assumptions about information systems underlying the statements being made.

Several authors acknowledge the existence of different definitions, difficult to conciliate, and present and discuss some of those definitions (e.g., [Avison and Wood-Harper 1986], [Avison and Fitzgerald 1988], [Amaral 1994]). Normally they end up by selecting the definition, which they consider being more useful to their intentions and to the subject they intend to develop.

Some authors deeply discuss the concept of information system but they do not attempt to provide a short definition for it. This happens, for example,

${ }^{8}$ In the case of organizations that deal only with symbolic objects the information system will coincide with the organization. This doesn't mean that the IS4 coincides with an IS1 system. An insurence company is an example of such a situation where the IS4 system encompasses the whole organization but that cannot be considered as an IS1 information system. 
in the books from Weber [Weber 1997] and Checkland and Holwell [Checkland and Holwell 1998]. Other authors avoid the issue of what an information system is by providing an enumeration of its components (e.g., [van Griethuysen 1982], [Kroenke and Dolan 1987], [Rolland, et al. 1988]).

Table 4 presents some definitions and assertions about information found in the literature systems (ordered chronologically by year of publication) and associates to each one the ISs that, in the author's opinion, correspond to the definition or fit the assertion. The association established between each definition and one or more IS depends on the personal interpretation of the author for each definition found. This brings a subjective dimension in the study but is unavoidable due to the nature of the human language and of the learning process. It should also be noted that terms such as information might be used with different meanings in different definitions.

Table 4. Some definitions of information system and the corresponding ISs

\begin{tabular}{|l|l|l|}
\hline \multicolumn{1}{|c|}{ Reference } & \multicolumn{1}{|c|}{ Definitions } & \multicolumn{1}{|c|}{ ISs encompassed } \\
\hline [Davis 1974] & $\begin{array}{l}\text { "... an integrated man/machine system for providing } \\
\text { information to support the operations, management } \\
\text { and decision making functions in an organisation. } \\
\text { The system uses computer hardware, software, } \\
\text { manual procedures, management and decision } \\
\text { models and a data base." }\end{array}$ & $\begin{array}{l}\text { IS2, IS4; } \\
\text { IS3 are considered } \\
\text { as being part of the } \\
\text { system }\end{array}$ \\
\hline $\begin{array}{l}\text { Le Moigne9 } \\
197 ?\end{array}$ & $\begin{array}{l}\text { "... can in effect be considered as the memorisation } \\
\text { system of the organisation: the system which permits } \\
\text { it to keep in memory: its transactions with its } \\
\text { environment; the events in its environment which it } \\
\text { wishes to recall easily for some period; the common } \\
\text { rationale which its members gladly share, or those } \\
\text { which are imposed by its environment" }\end{array}$ & IS2 \\
\hline $\begin{array}{l}\text { [van } \\
\text { Griethuysen } \\
\text { 1982], pp. 1- } \\
5\end{array}$ & $\begin{array}{l}\text { "... as consisting of a conceptual schema, an } \\
\text { information base, and an information processor". }\end{array}$ & $\begin{array}{l}\text { The elements } \\
\text { described can exist } \\
\text { in IS1, IS2, IS3 or } \\
\text { IS4 }\end{array}$ \\
\hline $\begin{array}{l}\text { [Avison and } \\
\text { Wood- } \\
\text { Harper 1986] }\end{array}$ & $\begin{array}{l}\text { "a system to collect, process, store, transmit, and } \\
\text { display information" }\end{array}$ & IS1, IS2, IS3, IS4 \\
\hline
\end{tabular}

9 This definition is presented in a document whose origin and date hasn't been possible to trace. It is a chapter of a book. The chapter is entitled "The FOUR-FLOWS MODEL as a Tool for Designing the Information System of an Organization" and corresponds to the pages 324 to 341 . At the end of the chapter, there is an abstract in German. The same view of information system is present in other documents produced by Le Moigne (e.g., [Le Moigne 1985], [Le Moigne 1977], [van Gigch and Le Moigne 1990], [Le Moigne 1978a], [Le Moigne 1978b], [Le Moigne 1979a], [Le Moigne 1979b]. 
Table 4 (cont.) Some definitions of information system and the corresponding ISs

\begin{tabular}{|c|c|c|}
\hline Reference & Definitions & ISs encompassed \\
\hline $\begin{array}{l}\text { [Buckingham, } \\
\text { et al. 1987], } \\
\text { pp.18 }\end{array}$ & $\begin{array}{l}\text { "... a system which assembles, stores, processes and } \\
\text { delivers information relevant to an organisation (or } \\
\text { to society), in such a way that the information is } \\
\text { accessible and useful to those who wish to use it, } \\
\text { including managers, staff, clients and citizens. An } \\
\text { information system is a human activity (social) } \\
\text { system which may or may not involve the use of } \\
\text { computer systems" }\end{array}$ & $\begin{array}{l}\text { IS1, IS2, IS4; } \\
\text { IS } 3 \text { are considered } \\
\text { as being part of the } \\
\text { system }\end{array}$ \\
\hline $\begin{array}{l}\text { [Kroenke and } \\
\text { Dolan 1987] }\end{array}$ & $\begin{array}{l}\text { "an information system consists of five } \\
\text { components: hardware, programs, data, procedures } \\
\text { and people }\end{array}$ & $\begin{array}{l}\text { The elements } \\
\text { described exist in } \\
\text { IS1, IS } 2 \text { or IS } 4 \text {; } \\
\text { IS } 3 \text { includes all but } \\
\text { one - people }\end{array}$ \\
\hline $\begin{array}{l}\text { adapted from } \\
\text { [Rolland, et } \\
\text { al. 1988] }\end{array}$ & $\begin{array}{l}\text { "... a set formed by: data; rules that define the } \\
\text { informational function; set of procedures to collect, } \\
\text { store, transform, retrieve, and communicate } \\
\text { information; set of human resources and technical } \\
\text { means, integrated within a system, that cooperate } \\
\text { and contribute to its function and to achieve its } \\
\text { purpose" }\end{array}$ & $\begin{array}{l}\text { The elements } \\
\text { described exist in } \\
\text { IS1, IS2 or IS4; } \\
\text { IS3 includes all but } \\
\text { one - human } \\
\text { resources }\end{array}$ \\
\hline $\begin{array}{l}\text { [Parker } \\
\text { 1989], pp.10 }\end{array}$ & $\begin{array}{l}\text { “... any system that provides to people with either } \\
\text { data or information relating to an organisation's } \\
\text { operations." }\end{array}$ & $\begin{array}{l}\text { IS3; can also fit IS2 } \\
\text { and IS4; }\end{array}$ \\
\hline $\begin{array}{l}\text { [Ein-Dor and } \\
\text { Segev 1993], } \\
\text { pp. } 167\end{array}$ & $\begin{array}{l}\text { "... any computerised system with a user or operator } \\
\text { interface }[\ldots . .] \text { provided the computer is not } \\
\text { physically embedded". }\end{array}$ & IS3 \\
\hline $\begin{array}{l}\text { [Wand, et al. } \\
1995], \mathrm{pp} . \\
287\end{array}$ & "... represents a perceived real-world system." & $\begin{array}{l}\text { This definition can } \\
\text { be applied to part of } \\
\text { the information IS1, } \\
\text { IS2, IS3 and IS4 } \\
\text { deal with }\end{array}$ \\
\hline $\begin{array}{l}\text { [Hirschheim, } \\
\text { et al. 1995], } \\
\text { pp. } 11\end{array}$ & $\begin{array}{l}\text { "structural perspective: a collection of people, } \\
\text { processes, data, models, technology and partly } \\
\text { formalised language, forming a cohesive structure } \\
\text { which serves some organisational purpose or } \\
\text { function. } \\
\text { functional perspective: technologically } \\
\text { implemented medium for the purpose of recording, } \\
\text { storing and disseminating linguistic expressions as } \\
\text { well as for the supporting of inference making" }\end{array}$ & $\begin{array}{l}\text { The elements } \\
\text { described in the } \\
\text { structural } \\
\text { perspective exist in } \\
\text { IS1, IS2 or IS4; } \\
\text { IS3 includes all but } \\
\text { one - human } \\
\text { resources; } \\
\text { The functional } \\
\text { perspective fits IS1, } \\
\text { IS2, IS3 and IS4 }\end{array}$ \\
\hline
\end{tabular}


Table 4 (cont.) Some definitions of information system and the corresponding ISs

\begin{tabular}{|l|l|l|}
\hline \multicolumn{1}{|c|}{ Reference } & \multicolumn{1}{|c|}{ Definitions } & \multicolumn{1}{|c|}{ ISs encompassed } \\
\hline pplter 1996], & $\begin{array}{l}\text { “... a system that uses information technology to } \\
\text { capture, transmit, store, retrieve, manipulate, or } \\
\text { display information used in one or more business } \\
\text { processes." }\end{array}$ & $\begin{array}{l}\text { IS3; } \\
\text { IS1, IS2 and IS4 } \\
\text { might be included if } \\
\text { they most rely on } \\
\text { computers and } \\
\text { computer-based } \\
\text { devices }\end{array}$ \\
\hline $\begin{array}{l}\text { [Falkenberg, } \\
\text { et al. 1996], } \\
\text { pp. 74, 211 } \\
\text { (FRISCO } \\
\text { Report) }\end{array}$ & $\begin{array}{l}\text { "... is a sub-system of an organisational system, } \\
\text { comprising the conception of how the } \\
\text { an organisation are composed (e.g., of specific } \\
\text { communicating, information-providing and/or } \\
\text { information seeking actors, and of specific } \\
\text { information-oriented actands) and how these } \\
\text { operate, thus describing the (explicit and/or explicit) } \\
\text { communication-oriented and information-providing } \\
\text { actions and arrangements within that organisation." }\end{array}$ & $\begin{array}{l}\text { Attending to the } \\
\text { FRISCO's definition } \\
\text { of information, fits a } \\
\text { sub-set of IS4; } \\
\text { Includes IS2; } \\
\text { report as } \\
\text { computerised } \\
\text { information system }\end{array}$ \\
\hline
\end{tabular}

\section{INFORMATION SYSTEM DEFINITIONS: DISCUSSION}

The first conclusion to draw from the previous section, is that most of the times, authors do not distinguish among the four things presented in section 3 as candidates to be considered information systems.

None of the definitions presented in the previous section, addresses IS1 in particular. This is not surprising, attending to the tradition in the IST area. IS1s are perhaps interesting to library science or other areas concerned with the creation of information services. However, things might be changing. The emergence of IT based information services is demanding that more attention is paid to the study of such services as information systems.

Only one definition addresses explicitly IS2. In fact, the view underlying IS2 has not been very exploited within the IST area. This view of information systems, based on the cybernetic and systemic approaches, provides an interesting basis to understand organisations as learning and acting systems, thus providing a promising framework to support the study of knowledge management. This view is also important to the general activity of organisational design and to other activities related with organisational design such as business process reengineering or even the determination of the information needs of organisational agents (either managers or operators).

IS3 and IS4 are often mixed in such a way that it is difficult to separate them. The only feature that can be used to distinguish among them is 
whether or not they include human agents. This "fusion" of IS3 and IS4 is perhaps due to the fact that IST people like to emphasise that they are not interested in just IT applications - IS3 systems. IT applications are interesting when studied in their context which includes the people that use them and the activities where they are used. Davis' definition [Davis 1974], for example, suggests this interpretation. It is normally used by those involved in the development of information systems (which is commonly understood as covering the earlier steps of software engineering projects, including the determination of requirements for computer-based systems) and (computerbased) database design. It is present in many textbooks about systems analysis and design, database design and information systems development (e.g., SAD [Yourdon 1989]; SSADM [Downs, et al. 1992], [Cutts 1991]; MULTIVIEW [Avison and Wood-Harper 1990]; OOA [Coad and Yourdon 1991]; [Hoffer, et al. 1999]). The problem with this view of information systems is that it dilutes the separation between IS3 and IS4. Very often, there is no explicit reference to the fact that it is necessary to study a wider information system (an organisational system that deals with information) in order to decide which kind of IT support can be provided to that system (computer-based information systems). In fact, there are two different types of systems (both can be considered to be information systems) and it isn't always advantageous to view them as just one system. The separation between the two types of systems is stressed by Checkland and his collaborators ([Checkland and Holwell 1998], [Winter, et al. 1995]) who refer to the relationship between IS3 and IS4, as a serving and a served system. It becomes clear that the study of serving system demands the study of the served system, i.e., both systems have to be dealt with. But it doesn't mean that both systems should be considered as just one.

Few authors use the term information systems to refer solely to IS3 without mixing them with IS4 (e.g., [Ein-Dor and Segev 1993]), although IS3 are sometimes identified as sub-systems of IS4 (e.g., FRISCO computerised information systems).

Among the definitions related to IS4 it is possible to identify two streams, distinguished by a subtle difference. The first one stresses that information systems must include information technology. This view underlies Davis' definition and perhaps Alter's as well (Alter's definition seems to be more focused on IS3s but it doesn't exclude completely IS4s). The other stream rather emphasises that the use of computer-based technology is incidental. Information systems are viewed as independent from the nature of their agents, i.e., independent from the technology used to implement them. Such view is suggested by the definitions of [Buckingham, et al. 1987], [Rolland, et al. 1988], [Hirschheim, et al. 1995], [Falkenberg, et al. 1996]. Other authors also seem to share this view (e.g., [Stamper 1997], [Carvalho and 
Amaral 1993]). It is interesting to note that the first stream can be associated to an American tradition while the second corresponds to a European tradition.

The IS4 view is very useful in another context - the professional activity of planning, deploying and maintaining (i.e., managing) the technological infrastructure for the information handling activities of an organisation. This activity is similar to the activity of managing other infrastructures for things such as water, electricity, air-conditioning, vapour, or sewage. The IT infrastructure of an organisation includes: transmission network (cables, sockets, infra-red or radio receptors and emitters, rooters, servers, etc.); storage servers; processing servers; workstations; information collection devices, printers and other presentation devices. The IS4 view is adequate to these activity, because it provides a "blueprint" of the information handling activities where the IT requirements of each activity can be mapped and where the connections among different devices can be outlined.

The IS4 view is also adopted to support business process reengineering (BPR) projects, specially when they are motivated by intentions of IT adoption. However, BPR projects could benefit from combining this view with an IS2 view, as this one enforces the importance of control mechanisms necessary in any process.

Table 5 summarises the professional domains where each of the IS views might be useful.

Table 5. Professional domains where each IS view is useful

\begin{tabular}{|c|l|}
\hline IS & \multicolumn{1}{c|}{ Professional domain } \\
\hline IS1 & Devising and management of information services \\
\hline IS2 & $\begin{array}{l}\text { Organisational design; determination of information needs of managers } \\
\text { and operators; knowledge management; business process reengineering }\end{array}$ \\
\hline IS2 \& IS3 & $\begin{array}{l}\text { Determination of requirements for computer-based systems; information } \\
\text { systems development; data base design }\end{array}$ \\
\hline IS3 & Design and construction of computer-based systems \\
\hline IS3 \& IS4 & $\begin{array}{l}\text { Information systems development; data base design; determination of } \\
\text { requirements for computer-based systems }\end{array}$ \\
\hline IS4 & $\begin{array}{l}\text { Information systems planning; business process reengineering (IT } \\
\text { driven); design and management of the IT infra-structure }\end{array}$ \\
\hline
\end{tabular}

All the professional domains listed in table 5 are normally recognised as being strongly related to the IST area and dealing with information systems. However, they focus on different types of systems. This is often hidden under definitions of information systems which are broad enough to encompass all the four ISs identified in section 3 but that fail to alert to the existence of different types of systems, whose deep understanding relies in knowledge borrowed from quite different disciplines. 


\section{CONCLUSIONS}

Any definition of information system is inevitably a general statement that can fit different instances. The situation in the IST area is that the existing definitions do not allow to properly identifying the objects that are in the mind of their proponents. The main reason to this seems to be related with some freedom on the use of the concept system.

The use of a more strict definition of system contributed to the identification of four different types of objects that can legitimately be considered as information system. The differences among them were stressed, the importance of distinguishing among them was referred, and their applicability and usefulness was discussed. Some of the assertions made about the role of certain IS views in some professional activities still demand confirmation. For example, the usefulness of an IS2 view in activities such as knowledge management or business process reengineering is not evident. Further research work pursuing this suggestion should first be accomplished.

An analysis of some information systems definitions found in the IST literature confirmed that they can correspond to more that one object. Although in some cases this is not harmful, in other situations it leads to confusion about what is the object of interest of a professional activity or a scientific domain. Moreover, this confusion contributes to the difficulty on establishing a terminology consensus in the IST discipline, which then contributes to the difficulty on establishing a shared core to the discipline.

\section{REFERENCES}

Ackoff, R.L., "Towards a Systems of Systems Concepts", Management Science, 17, 11 (1971), 661-671.

Alter, S., Information Systems: A Management Perspective, The Benjamin/Cummings Publishing Company, 1996.

Amaral, L.A.M.d., PRAXIS: Um referencial para o Planeamento de Sistemas de Informação, Tese de Doutoramento, Universidade do Minho, 1994 (in Portuguese).

Avison, D.E. and G. Fitzgerald, Information Systems Development: Methodologies, Techniques and Tools, Blackwell, 1988.

Avison, D.E. and A.T. Wood-Harper, "Multiview - An Exploration in Information Systems Development", The Australian Computer Journal, 18, 4 (1986), 174-179.

Avison, D.E. and A.T. Wood-Harper, MULTIVIEW: An Exploration in Information Systems Development, Blackwell Scientific Publications, 1990.

Bacon, C.J. and B. Fitzgerald, The Field of IST: A Name, a Framework, and a Central Focus, Research Report, 1996.

Boulding, K.E., "General Systems Theory: The Skeleton of Science", Management Science, 2, 3 (1956), 197-208. 
Boulding, K.E., The World as a Total System, Sage Publications, 1985.

Buckingham, R.A. R. Hirschheim F.F. Land and C.J. Tully, "Information Systems Curriculum: a Basis for Course Design" in Buckingham, R.A. R. Hirschheim F.F. Land and C.J. Tully, Information Systems Education: Recommendations and Implementation, Cambridge University Press, 1987., 1987.

Bunge, M., A World of Systems, D. Reidel Publishing Company, 1979.

Carvalho, J.A., "Using the Viable System Model to Describe the Role of Computer-Based Systems in Organisations" in Callaos, Nagib, Linda Holmes and Rodolfo Osers (Eds.), Proceedings of the SCI'98 - World Multiconference on Systems, Cybernetics and Informatics, July 12 - 16, Orlando USA, Volume 4, 1998.

Carvalho, J.Á. and L. Amaral, "Matriz de Actividades: Um Enquadramento Conceptual para as Actividades de Planeamento e Desenvolvimento de Sistemas de Informação", Sistemas de Informação, 1 (1993), 37-48 (in Portuguese).

Checkland, P. and S. Holwell, Information, Systems and Information Systems: Making Sense of the Field, John Wiley \& Sons, 1998.

Checkland, P.B., Systems Thinking, Systems Practice, John Willey \& Sons, 1981.

Coad, P. and E. Yourdon, Object-Oriented Analysis, Yourdon Press/Prentice-Hall, 1991.

Cutts, G., Structured Systems Analysis and Design Methodology, Blackwell, 1991.

Davis, G.B., Management Information Systems: Conceptual Foundations, Structure, and Development, McGraw-Hill, 1974.

Downs, E. P. Clare and I. Coe, Structured Systems Analysis and Design Method, Prentice Hall, 1992.

Ein-Dor, P. and E. Segev, "A Classification of Information Systems: Analysis and Interpretation", Information Systems Research, 4, 2 (1993), 166-204.

Falkenberg, E. W. Hesse P. Lindgreen B.E. Nilssen J.L.H. Oei C. Rolland R.K. Stamper F.J.M.V. Assche A.A. Verrijn-Stuart and K. Voss, FRISCO: A Framework of Information Systems Concepts, IFIP WG 8.1 Task Group FRISCO, 1996.

Falkenberg, E.D. and P. Lindgreen (Eds.), Information Systems Concepts: An In-depth Analysis, North-Holland, 1989.

Falkenberg, E.D. C. Rolland and E.-S.N.-E.-.D. El-Sayed (Eds.), Information Systems Concepts: Improving the Understanding, North-Holland, 1992.

Hirschheim, R. H.K. Klein and K. Lyytinen, Information Systems Development and Data Modelling: Conceptual and Philosophical Foundation, Cambridge University Press, 1995.

Hoffer, J.A. J.F. George and J.S. Valacich, Modern Systems Analysis and Design, AddisonWesley, 1999.

Jordan, N., Themes in Speculative Psychology, Tavistock Publications, 1968.

Kroenke, D. and K.A. Dolan, Business Computer WSystems: An Introduction, Mitchell Publishing, 1987.

Laszlo, E., Systems Science and World Order: Selected Studies, Pergamon Press, 1983.

Le Moigne, J.-L., La Théorie du Système Général: Théorie de la Modélisation, Presses Universitaires de France, 1977 (in French).

Le Moigne, J.-L., "Towards New Epistemological Foundations for Information Systems", Systems Research, 2, 3 (1985), 247-251.

Le Moigne, J.L., La Théorie du Système d' Information Organisationnel, 1978a (in French). 
Le Moigne, J.L., La Théorie du Système d' Information Organisationnel: 2 La Définition Fonctionelle du SIO, 1978b (in French).

Le Moigne, J.L., La Théorie du Système d' Information Organisationnel: 3 La Définition Génétique du SIO, 1979a (in French).

Le Moigne, J.L., La Théorie du Système d'Information Organisationnel: 4 La Définition Organique du SIO, 1979b (in French)

Mingers, J. and F. Stowell (Eds.), Information Systems: An Emerging Discipline?, McGrawHill, 1997.

Parker, C.S., Management Information Systems: Strategy and Action, McGraw-Hill, 1989.

Rolland, C. O. Foucault and G. Benci, Conception des Systèmes d'Information: La Méthode Rémora, Editions Eyrolles, 1988 (in French).

Skyttner, L., General Systems Theory: An Introduction, Macmillan Press, 1996.

Stamper, R., "Organisational Semiotics" in Mingers, J. and F. Stowell (Eds.), Information Systems: An Emerging Discipline?, McGraw-Hill, 1997., 1997.

van Gigch, J.P., Applied General Systems Theory, Harper \& Row Publishers, 1974.

van Gigch, J.P., System Design Modeling and Metamodeling, Plenum Press, 1991.

van Gigch, J.P. and J.-L. Le Moigne, "The Design of an Organisation Information System:

Intelligent Artefacts for Complex Organisations", Information \& Management, 19, (1990), 325-331.

van Griethuysen, J.J. (Eds.), Concepts and Terminology for the Conceptual Schema and Information Base, Report ISO TC97/SC5 - N 695 from the ISO working group ISO TC97/SC5/WG3 - Conceptual schema, 1982.

von Bertalanffy, L., Perspectives on General Systems Theory: Scientific-Philosophical Studies, George Braziller, New York, 1975.

Wand, Y. D.E. Monarchi J. Parsons and C.C. Woo, "Theoretical Foundations for Conceptual Modelling in Information Systems Development", Decision Support Systems, 15, 4 (1995), 285-304.

Wand, Y. and R. Weber, "An Ontological Evaluation of Systems Analysis and Design Methods" in Falkenberg, E.D. and P. Lindgreen, Information Systems Concepts: An Indepth Analysis, North-Holland, 1989.

Wand, Y. and R. Weber, "An Ontological Model of an Information System", IEEE Transactions on Software Engineering, 16, 11 (1990), 1282-1292.

Wand, Y. and R. Weber, "On the Ontological Expressiveness of Information Systems Analysis and Design Grammars", Journal of Information Systems, 3, (1993), 217-237.

Wand, Y. and C.C. Woo, Object-Oriented Analysis: Is it Really Simple?, Faculty of Commerce and Business Administration, The University of British Columbia, 1996?

Weber, R., Ontological Foundations of Information Systems, Coopers \& Lybrand, Australia, 1997.

Winter, M.C. D.H. Brown and P.B. Checkland, "A Role for Soft Systems Methodology in Information Systems Development", European Journal of Information Systems, 4, (1995), 130-142.

Yourdon, E., Modern Structured Analysis, Prentice-Hall, 1989. 